\title{
The Rejuvenation of the Withering Nation State and Bio-power: The New Dynamics of Human Interaction
}

\author{
Abdul Wahab Suri
}

Received: 12 May 2020 / Accepted: 3 August 2020

(C) Journal of Bioethical Inquiry Pty Ltd. 2020

\begin{abstract}
The outbreak of COVID-19 comes at the time when a shrinking public sector healthcare is an acknowledged fact in post-colonial societies. The policies adopted by the apparatus of most nation states for the past thirty years or more reveal that providing healthcare to all sections of societies is not a priority. The gradual process of economic liberalization has established "market" as the only legitimate mechanism of the distribution of goods/services as per the efficiency principle. The financial markets are globalized in such a manner that nation states are constantly losing their capacity to perform redistributive functions. State withdrawal from the provision of welfare rights is undermining its moral authority to impose any normative imperative to the people who are being left alone at the mercy of market forces. But the spread of COVID-19 on a global scale has provided an opportunity to the nation state. With the help of healthcare systems, the State has reasserted itself as the ultimate archangel to define human beings and their respective status in the newly emerging nomenclature of the public sphere. In this paper, the rejuvenation of the nation state with respect to bio-power will be discussed in the postcolonial context.
\end{abstract}

Keywords Governmentality · Bio-power · Healthcare COVID-19

\footnotetext{
A. W. Suri $(\bowtie)$

Department of Philosophy, University of Karachi, Karachi, Pakistan

e-mail: wahabsuri@gmail.com
}

\section{The COVID-19 Discourse and Bio-Power}

"Who am I?" The central etiological question of human beings has been reasserted once again due to the COVID-19 pandemic. The normative imperative adopted by human beings, that is, "How should I be?", is generally derived from the answer to the first question. Thus any substantive change to our ontological status will radically transform the epistemological, axiological and, most importantly, political dynamics of the given metrics in which we all have been situated.

COVID-19 and the virus that causes it (severe acute respiratory syndrome coronavirus 2 (SARS-CoV-2)) have given us a new identity as actual or potential carriers. Unlike some other established pandemic diseases, such as leprosy and plague, the asymptomatic presence of the virus has made it more insidious. The fact that human capacity to deal with COVID-19 entails not only a physiological adaptability but also social and economic dislocation may pose a challenge to the nation-state model. The normative challenge is more acute, because my status as a human being, that is, as someone who answers the questions "who am I?" and "how I should be?", is not easily answered by the nation-state. The COVID-19 discourse will last for a long time because the nation state has had to reverse once again its withering role in the determination of my status as a human being.

The reasserted authority of the state is legitimized by prevailing assumptions, which are interwoven into the fabric of mass media and presented as non-contestable axioms. The assumptions are as follows: 
- COVID-19 is an issue of healthcare.

- The state is responsible for ensuring the healthcare of its citizens.

- Death is avoidable by the application of a superior mechanism of control and surveillance.

This paper will critically analyse these assumptions and revisit our general understanding of healthcare. It will be argued that COVID -19 has provided us with an opportunity to break our shackles of self-estrangement, to listen to the call of consciousness, and to regain our authentic mode of existence (Langan 1959, 34).

The cure of disease and suffering is the prime concern of healthcare. However, the sudden outbreak of COVID-19 has exposed the capacity and response potential of the global healthcare apparatus. The damage caused by only a single virus at the global level has been phenomenal. The fact is that we are surrounded by "an estimated ten nonillion (ten to the thirty-first power) individual viruses on our planet - enough to assign one to every star in the universe one hundred million times over" (Wu 2020).

The issue which has shattered the global order goes beyond the disease and the deaths caused by the virus, it is about the management of carriers and the establishment of a mechanism for differentiating carriers from non-carriers. The crisis is not a matter of "cure" or control of the increasing death toll but the management and the control of masses in the absence of an ultimate therapeutic protocol for treating the disease.

Therefore, it is reasonable to argue that the contemporary crisis is a crisis of governmentality (Foucault 2007, 56-57). The global outbreak of the virus has revealed the limitations of the extant mechanism of governmentality. The incapacity of some advanced nation-states to control the masses through their frameworks of governmentality is leading to a revival of disciplinary power in the First World. On the other hand, where modern institutions of control are not comprehensively institutionalized, as in many Third World countries, the sovereign power of the state has merely been imposed arbitrarily. The global lockdown has provided us with an opportunity to obtain first-hand experience of these different power dynamics in concrete life-worlds. According to Foucault, "baldly at first sight and somewhat schematically we could say that sovereignty is exercised within the borders of territory, discipline is exercised on the body of the individuals, and security is exercised over the whole population" (Foucault 2007, 11-12).

"Sovereignty" is the right of the government to exercise power over its people without any interference from outside. The traditional monarchical power is one of the representations of sovereign power, where power is centralized and cannot be challenged. In many parts of the world, states are instrumentalizing this type of power to discipline people in order to control the wide spread of the virus. The brute expression of state power is working because state authorities are seeking legitimacy from healthcare professionals for the use of coercive measures.

"Disciplinary power" is asserted through modern institutions. "Discipline classifies the component thus identified according to definite objectives" (Foucault 2007, 56). The expression of power is exercised through disciplinary means, that is, through a variety of institutions like schools, hospitals, prisons, executive and legislative institutions, etc. In this context, the legitimacy of disciplinary power is derived from the dictations of acknowledged authority in the respective area of concern. Disciplinary power cannot be effective without institutionalized knowledge. In accordance with this, in healthcare all the standard procedures of operations are dominated by professionals. The disseminated knowledge embedded in modern institutions allows the latter to assess, evaluate, analyse, observe, and foster the psyches of the people. Thus, institutions create knowledge and legitimize power expression. This expression of power is manifested in the usual modes of the operation of state authority in many parts of the world. This institutionalized expression of power, discipline, and surveillance can operate in profound ways, and these may be both beneficent and malign as per the discretion of state apparatus. The COVID-19 pandemic has opened up a new avenue to assert coercion and control.

The history of political theory reveals that the "power of ruling" which was expressed in pre-modern epochs has gradually transformed into "power of governing." This power of governing presents itself as emancipatory. Unlike juridical power, the invisible expression of power creates an illusion of self-governance; it invites human subjects to participate in the governing process. It is not just the power of rules or orders but rather of the questions: "who am I?" and "how should I behave?" It expands the area of control from the public sphere to the dynamics of individual thought. The power of 
governmentality instructs individuals to govern themselves and shifts power from central authority to the people. Sovereignty inhering within people has resulted in instances of violence and murder by individuals against other individuals, violating the operational principles designated by the state authorities. Many people have committed suicide after they have tested positive for COVID-19.

Governmentality instils or inculcates people to control themselves, their expression and their thought for the benefit of the power institutions. Thus, the successful instillation of governmentality is dependent on people participating and consenting to governing processes and procedures.

COVID-19 alerts us to the expression of all these three forms of power at play simultaneously. The role of the healthcare apparatus is decisive because without healthcare professionals bio-power cannot be substantiated. According to Foucault "by this [bio- power] I mean a number of phenomena that seems to me to be quite significant through which the basic biological features of the human species become the object of a political strategy of a general strategy of power" (2007, 1). It means that after the normalization of the contemporary traumatic situation one can anticipate new forms of regimentation, surveillance, stratification, segmentation, discrimination, confinement and security protocols, both at home and abroad.

Let's move towards the second assumption, that healthcare is the responsibility of the nation state. In our part of the world (Pakistan) the people in power are constantly informing those who are not that, given that the virus is so contagious, they will be unable to provide healthcare to everyone who is infected or likely to be infected. For this reason, the people are ordered to control themselves. "Social distancing" has been presented as an effective solution to avoid infection.

This discourse at the subliminal level conveys the false assumption that under normal circumstances the public sector healthcare apparatus is actually capable of accommodating all the sick people affected by diseases other than COVID-19 - which is, of course, untrue. "At least half of the world's population cannot obtain essential health services, according to a new report from the World Bank and WHO" (World Health Organization 2017).

Statistics regarding the available healthcare facilities in Pakistan just two years before the COVID-19 outbreak show that healthcare was not in fact a priority for the government. The public sector healthcare apparatus is in shambles and the number of people who do not have any access to healthcare is high. In the field of healthcare, the state has been withering away while the private sector has been flourishing. The WHO report claims that

800 million people spend at least 10 per cent of their household budgets on health expenses for themselves, a sick child or other family member. For almost 100 million people, these expenses are high enough to push them into extreme poverty, forcing them to survive on just $\$ 1.90$ or less a day. (World Health Organization 2017).

The commodification of diseases and healthcare systems are a bitter truth of our lives.

In many Third World countries, people who are under a coercive order of lockdown do not expect any healthcare facilities to cure COVID-19. Therefore, they are hesitant to inform authorities about their health conditions and instead utilize traditional methods to combat the virus. The inability of the Third World public sector to provide healthcare solutions to all sick people is not surprising because we all are conditioned to these limitations. But the shortcomings we are now witnessing in the First World or "affluent" world implies stringently that we should all revisit our healthcare frameworks. The withering role of the nation state for providing basic healthcare to all needs to be addressed promptly, as an emergency.

\section{COVID-19 and the Authentic Mode of Existence}

"The wound is the place where the light enters you" Rumi (Jalāl ad-Dīn Muhammad Balkhī 1207-1273)

The COVID-19 pandemic has raised questions about two very important things that directly affect the meanings of our lives:

a) It has questioned the role of the "other" in our lives, i.e., "the they."

b) It has questioned the centrality of routine life, i.e., the "everydayness." 
Both of these factors, "the they" and "everydayness", according to Heidegger, are sources of an inauthentic mode of our existence.

COVID-19 has also introduced a "consciousness of death" into the public sphere, which had formerly been colonized by the discourse of life. The governing mechanisms of consumption and production have presented death as something which can be postponed by a better and more capital intensive healthcare apparatus. That is why in our part of the world whenever affluent people get sick they prefer to move abroad.

The pandemic outbreak and its high death toll in advanced industrial societies has provided us with an opportunity to revisit the phenomenon of "death" in the context of its ontological foundations. The discourse of death under the controlled conditions of quarantine enables us to revisit the notion of "our existence" and its ontological and intentional relation with death. The lopsided focus on the biological notion of death has abandoned the ontological necessity of "being-towards-end" (Heidegger 1962, 313). Heidegger considers death as a mode of being to which our existence, our Dasein, is exposed. The consciousness of death is essentially the authentic mode of Dasein, that is, the being-towardsthe-death. This consciousness of death makes sense of our life. Humans oscillate between authentic and inauthentic modes of existence, with the freedom to choose which ever project suits them best (Langan 1959, 3334).

The routine life embedded in our "everydayness" reminds us of our being-in-the-world and gravitates us towards self-estrangement (Brocke 1953, 56-57). This self-estrangement means that we constantly strive towards awareness of something other than our selves. The everyday mode of Dasein in verfallen has been broken by COVID-19 and has provided us with an opportunity to go beyond distantiality (Heidegger 1962, 164-165). Distantiality, according to Heidegger, is the character of being-with-one-another in which the self is subjugated, pejoratively taking away the Dasein's concern with its own being and replacing it with "other," i.e., "the they." Because of distantiality, when an individual loses his/her/their self in a football stadium, or in a concert, or in a public protest, or in a marathon race, or in a stock market numerical fluctuation, or in a social media like/dislike, the being-with-one-another liquefies or melts one's own Dasein into a being-of-the-other. In self-estrangement, we seek pleasure with the eye of "the they."

The new consciousness of death brings Dasein back to the authentic mode of being-one's- self (Heidegger 1962, 313). This authentic mode of Dasein by the modification of "the they" makes us self-aware of differences in the public sphere and, most crucially, the fact that racial, ethnic, gender, and class distinctions, including also value addition and fashion trends, are meanings imputed by the consciousness whose ultimate potentiality is death.

COVID-19 provides us with an opportunity at a global level to revisit our existential problems in the authentic mode, that is, the mode geared towards our demise, death, and destruction. Let us seize this opportunity to go even further and revisit the challenges of environment, healthcare, social injustice, and discrimination so that we can make a better world in the postCOVID-19 age.

\section{References}

Brocke, W. 1953. Existence and being by Martine Heidegger. London: Vision Press.

Foucault, M. trans. 2007. Security, territory, population: Lectures at the Collage De France 1977-78. Edited by M. Senellart. Translated by G. Burchell. London: Palgrave Macmillan.

Heidegger, M. 1962. Being and Time. Translated by J. Macquarrie and E. Robinson. New York: Harper and Row.

Langan, T. 1959. The Meaning of Heidegger: A critical study of an existentialist phenomenology. New York: Columbia University Press.

World Health Organization. 2017.News release: World Bank and WHO: Half the world lacks access to essential health services, 100 million still pushed into extreme poverty because of health expenses, December 13. https://www.who. int/en/news-room/detail/13-12-2017-world-bank-and-whohalf-the-world-lacks-access-to-essential-health-services-100million-still-pushed-into-extreme-poverty-because-ofhealth-expenses Accessed July 29, 2020.

Wu, K.J. 2020. There are more viruses than stars in universe. Why do only some infect us? National Geographic, April 15. https://www.nationalgeographic.com/science/2020/04 /factors-allow-viruses-infect-humans-coronavirus/. Accessed July 27, 2020.

Publisher's Note Springer Nature remains neutral with regard to jurisdictional claims in published maps and institutional affiliations. 